\title{
HYDRAULIC PARAMETERS AND MORPHOMETRIC VARIABLES INTERACTIONS IN BEDROCK CHANNEL
}

\author{
Biswajit Biswas, Balai Chandra Das \\ Department of Geography, Krishnagar Govt. College, Krishnagar, India
}

Manuscript received: May 20, 2016

Revised version: August 11, 2016

\begin{abstract}
BISWAS B., DAS B. C., 2016. Hydraulic parameters and morphometric variables interactions in bedrock channel. Quaestiones Geographicae 35(3), Bogucki Wydawnictwo Naukowe, Poznań, pp. 75-88, 12 figs.

ABSTRACT: Present study is on the interdependent nature of hydraulic parameters and morphometric variables of a bedrock river. In this study, using dumpy level, GPS, satellite images and some mathematical equations a data set on hydraulics and morphometric variables of a bedrock channel, named Bhatajhor, of eastern India was generated. That data set was used to (1) find out impulse-response relations between hydraulic variables (2) find out relations between morphometric variables and (3) find out relations between hydraulic and morphometric variables. Seven equations (5-11) were formulated based on this empirical study to the end. The seven empirical relations, most of which include only two variables, involve channel cross-section dimensions (area, width, mean depth, maximum depth, width/ depth ratio, hydraulic radius), slope and hydraulic variables (velocity, kinetic energy, stream power, Manning's $n$ factor, Chezy's C factor and shear stress). Observation shows relatively higher coefficient of determination (R2) between variables like velocity and Manning's $n$ factor (0.67), velocity and Chezy's $C$ factor $(0.67)$, slope and $\tau(0.89), \mathrm{w} / \mathrm{d}$ ratio and hydraulic radius (0.53), slope and $\mathrm{w} / \mathrm{d}$ ratio $(0.50)$.
\end{abstract}

KEY wORDS: width/depth ratio, channel slope, hydraulic radius, velocity, stream power

Corresponding author: Biswajit Biswas (e-mail: biswasb19@gmail.com)

\section{Introduction}

Rivers and river processes are one of the most important geomorphic systems operating on the earth system. Rivers continuously shape and reform their channels through erosion of the channel bed and banks and reworking and deposition of sediments. Two types of sub-systems are concerned with the fluvial system. These are morphological system and cascading system. Landform such as channels, hill slope and floodplains form a morphological system and the components of the morphological system are linked by a cascading system which refers to the flow of water and sediment through the morphological system. The two systems interact as a process-response system. This describes the adjustments between the process of the cascading system and the forms of the morphological system. This process-response system also depends on the geometry of channels and hydraulics. Channel geometry representing the size and shape of cross sectional and longitudinal channel form. These includes channel width, channel depth, wetted perimeter, channel slope, channel sinuosity etc. Hydraulic variables such as velocity, flow pattern, flow resistance, etc are maintained by interaction among the different variables of channel geometry. In fluvial system, variables are of three kind- form variables, hydraulics variables and process variables. All these 
variables, in terms of cause-effect relation can be classified into two categories - independent or controlling variables and dependant or adjustable variables (Leopold et. al. 1992, Huggett 2002, Charlton 2008). But the term 'variable' itself implies its nature of changeability. Therefore, the variable what is 'controlling' at one case is 'adjustable' at other case. As for example, velocity (controlling variable) determines the entrainment (adjustable variable) of particle of a given size. Channel slope (controlling variable) determines velocity (adjustable variable). Rate and nature (particle size and shape) of entrainment (controlling variable) determines the rate and processes of erosion (adjustable variable). Again there are two way feedbacks between forms and hydraulics - negative feedback and positive feedback. Both are initiated by a change in one of the system variables, which in turn leads to a sequence of adjustment that eventually, counteract the effect of the original change or enhance it. In other words, process shape forms and forms influence the way in which processes and hydraulics operate in channel.

Process-response systems have been studied extensively in different fluvial environments such as alluvial channel, bedrock channel and mixed channel. Alluvial channels amongst all these are explored the most. This is because of the maximum number of populations in the world are directly dependent on alluvial channel. In comparison with alluvial channels bedrock and mixed channels have received relatively little attention until recently (Selby 1985, Ashley et al. 1988, Wende 1999, Whipple et al. 2000). This is because of the minimum number of populations in the world are directly dependent on bedrock channel and difficult accessibility of these channels. Bedrock morphology is highly variable, even within a single reach (Tinker and Wohl 1998) and often reflects not just local stream hydraulics but also rock lithology and heterogeneity of joints, bedding, cleavage etc. Bedrock channel pose very high degree of difficulties for field and laboratory study. Change in channel forms are too slow to study in lifetime of a researcher. Yet bedrock channels play a great role in the scene of world ecosystem (Gurnell et al. 2001, Marzadri et al. 2010, Mosselman 2012, Nikora and Roy 2012). Bedrock channels supplies alluvium that forms substrate for the alluvial channel. Mountainous bedrock channels transport and deposit a considerable amount of organic carbon to alluvial plain and ocean (Battin 2008) which have a significant bearing on global warming and climate (Raymo et al. 1988, Raymo and Ruddiman 1992, Berner, and Berner 1996, Gaillardet et al. 1999, Galy and France-Lanord 2001, Galy et al. 2007, IPCC 2007). So at a variety of scales, numerous works have been done on bedrock channel. Ashley et al. (1988) and Itakura and Ikeda (1997) studied meandering bedrock channel. Relation between basin area and bedrock channel width was studied by Montgomery and Gran (2001) while Kobor and Roering (2004) performed study on basin area and channel slope of rivers over rocks. Miller (1991), Wohl et al. (1994), Seidl et al. (1996), Righter (1997), Weissel and Seidl (1997, 1998), Wohl and Ikeda (1998), Wohl (2000), Wohl and Merritt (2001), Wohl and Achyuthan (2002) contributed valuable work on knick points. Erosion rates in natural bedrock channels have been measured by Foley (1980), Smith et al. (1995), Righter (1997), Hancock et al. (1998), Tinkler and Parish (1998), Whipple et al. (2000b), Wohl and Achyuthan (2002), Kale and Joshi (2004), Reusser et al. (2004).

Despite all these numerous works on rivers over rocks, at lower end of the scale, bed forms and associated flow structure in bedrock channels are poorly described. Discharge and flow regime have controls on channel form (Harvey 1969, Stevens et al. 1975). Hydraulic geometry (Leopold and Maddock 1953) of channel is related to the volume of discharge through it. As adjustment of hydraulic geometry is multivariate complex adjustment mechanism, original formulas of hydraulic geometry (Leopold and Maddock 1953) are sophisticated more and more (Bates 1990, Rhoads 1992) to understand stream behaviour precisely. Being strongly influenced by the resistant nature of their substrate, bedrock channels often behave in a different way to alluvial channels. Forms and processes shaping them in bedrock channels and interaction among them are much different from as in the case of alluvial channel. In bedrock channel, channel substrate exerts a great influence on both forms as well as on processes. Structural controls, such as joints, bedding planes and underlying strata can all have a significant effect on flow process and channel morphology. Hydraulic geometry (Leopold and Maddock 1953) of bedrock channels are not so simply related to 
the dominant independent variable of discharge (Knighton 1998). Dependent variables of hydraulic geometry like width, depth, slope, and velocity do not follow the same principle of simple power function of independent variable of discharge as in case of alluvial channels.

According to Richardson and Carling (2005) bedrock channels are not common and are therefore unimportant. But this very nature of uniqueness of each channel creates vast expanding field for study of bedrock channel making it rather more important field of research. Leopold and Maddock (1953) found adjustment between independent hydraulic variable discharge $(Q)$ and dependent morphometric variables width $(\mathrm{w})$ and depth (d). They did their study on Powder River and its tributaries of mid west USA and found similar relationships between discharge and width and depth of a channel even for river systems very different in physiographic settings. Ferguson (1973) extended Leopold and Maddock's (1953) works and its study on sand bed rivers in the Great Plains of USA incorporated degree of cohesion of bank materials in terms of silt-clay co ntent (B). Schumm in 1971 added channel perimeter $(\mathrm{M})$ to establish relationship between discharge and width and depth. But relationships between hydraulic variables and adjusted channel forms or vice versa of bedrock channels are less studied. So, using already established equations of Froude Number, shear stress, Chezy's C factor, Manning's $n$ factor, stream power and kinetic energy in one hand and different morphometric variables on other hand, present work is aimed at putting light on hydraulic geometry of a bedrock channel Bhatajhor, a left bank tributary of Subarnarekha. Controls of longitudinal bars, boulder berms, steep escarpment, dolerite outcrops and rock obstacles bed forms on flow pattern at low water stage in one hand and controls of channel forms (width, depth and slope) on hydraulics at low water stage (velocity, shear stress, Manning's $n$ factor, Chezy's C factor) on other hand are also described in this paper.

\section{Study area}

For this empirical study on hydraulic parameters and morphometric variables interactions in bedrock channels, we selected lower reach of the river Bhatajhor. The Bhatajhor is a left tributary of the river Subarnarekha in its middle course, which joins the river Subarnarekha at Harindungri, a village $2 \mathrm{~km}$ south of Ghatsila. The Bhatajhor River is located in Ghatsila police station, Purbi Singhbhum district in the state of Jharkhand with an insular location in the tropical realm with monsoon climatic region. Latitudinal extension of its basin is from $22^{\circ} 34^{\prime} 09.18^{\prime \prime} \mathrm{N}$ to $22^{\circ} 38^{\prime} 21.81^{\prime \prime} \mathrm{N}$ and longitudinal extension from $86^{\circ} 28^{\prime} 56.22^{\prime \prime} \mathrm{E}$ to $86^{\circ} 30^{\prime} 11.34^{\prime \prime} \mathrm{E}$. This micro scale empirical study has been done on the lower reach of only 345.71 metres upwards from its confluence of the river (Fig. 1).

In middle Subarnarekha Basin i.e. Singhbhum crustal province, the major rock formations were apparently laid down during a number of distinct geological eras, each of which separated from the next by prolonged periods of erosion, earth movements or igneous activities (Mukhopadhyay 1980). The rocks of the Singhbhum area are mainly of two kinds - unmetamorphosed one in the south and the heavily metamorphosed one in the north separated by a major thrust zone (Singhbhum Shear Zone) extending from Porhat in western Singhbhum through Chakradharpur, Amada, Rakha mines, Mosaboni and Sunrgi into Mayurbhanj covering a distance of $160 \mathrm{~km}$. This thrust or shear zone marks the over folded limb of anticline (Fig. 2).

The unequal uplifts or tilts in the different parts of the basin have also caused the developments of striking differences in the topographic expressions within the basin. A doleritic dyke is running parallel to the left bank of the river Bhatajhor and as the dyke passes across Subarnarekha, it exerts great obstacle to the flow of the river Subarnarekha during monsoon months. Flow in Bhatajhor channel is also hindered by rock obstacles and left bank of the channel is in most cases delineated by doleritic wall.

The Middle Subarnarekha Basin area i.e. south eastern part of Chotanagpur plateau is characterized by Monsoonal climate but according to Koppen's (1936) climatic classification it falls under the semi arid (BS) climate. The temperature and rainfall vary with change of season. There is a sharp increase in temperature found in the pre monsoon period that is months of March to April until May and the river Bhatajhor receives only 


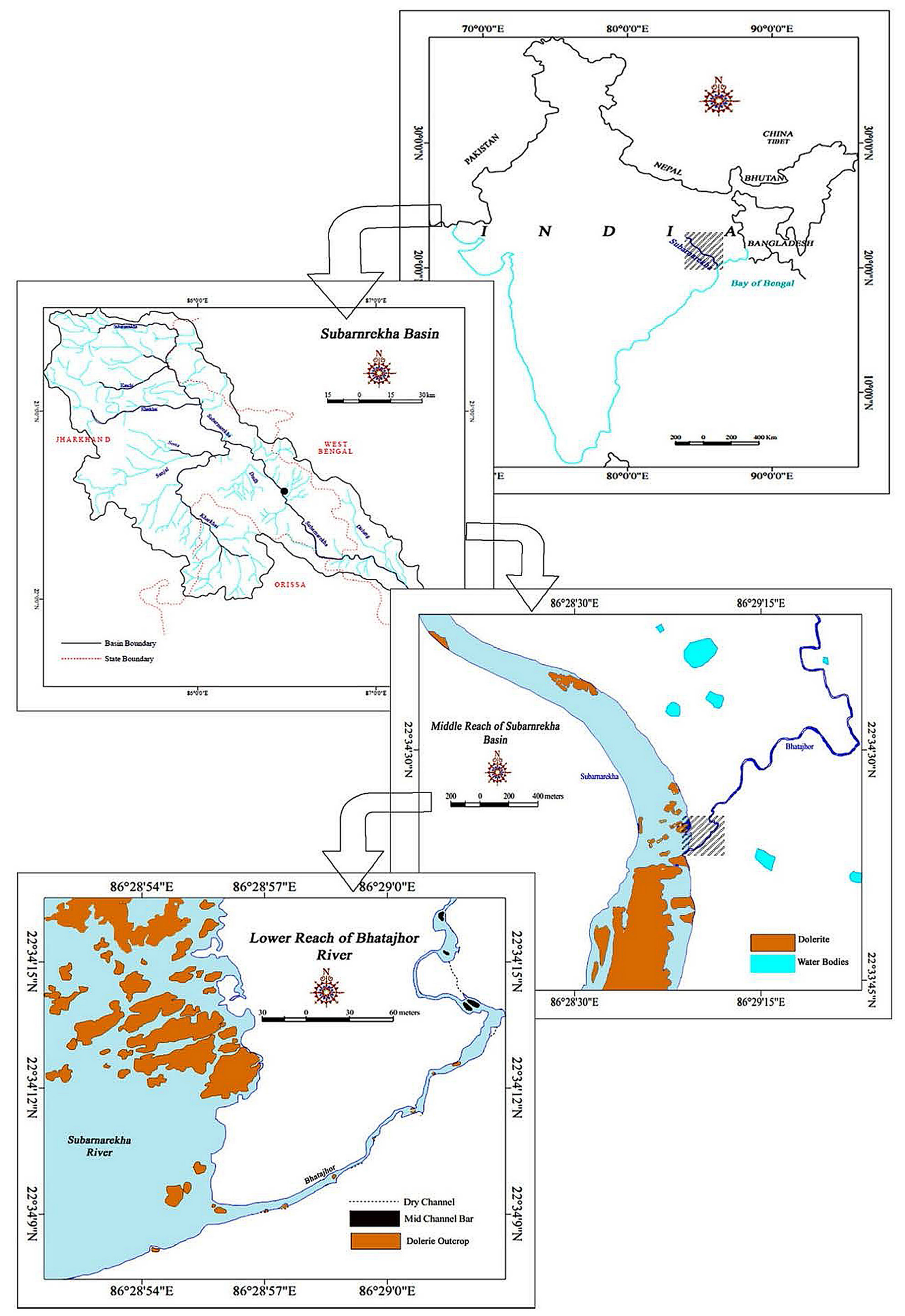

Fig. 1. Location of the study area. 


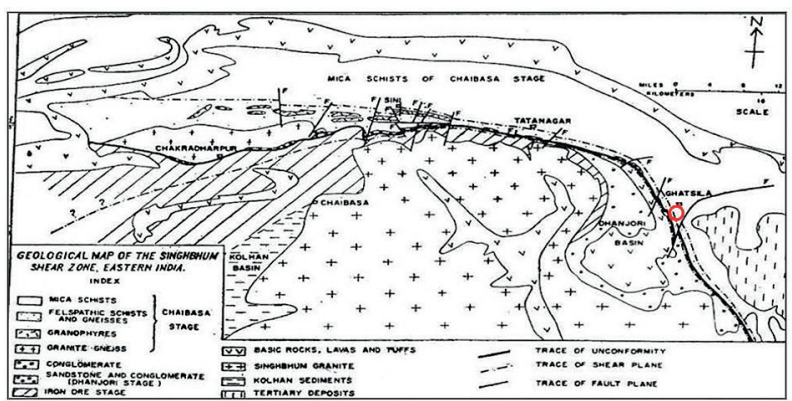

Fig. 2. Study area marked as red circle in the geological setup of the Singhbhum Shear zone (after Mukhopadhyay 1980).

seepage water to flow. During June and October the temperature begins to decrease with the onset of South West Monsoon making the river in its fullest vigour. Most of the seasonal rain fall (above $75 \%$ ) is occurs in this season. July is the wettest month of this region. Average rainfalls $1375 \mathrm{~mm}$. Lateritic soils are mingled with disintegrated rocks, boulders and gravels.

\section{Materials and Methodology}

Materials for this empirical study are data collected on width, average depth, maximum depth, wetted perimeter, water surface slope, channel bed slope, velocity and discharge at 16 stations (Fig. 3) over lower reach of $345.71 \mathrm{~m}$ of Bhatajhor River. Some bedrock features like riffle, pool, longitudinal bar, channel confinement, bedrock wall etc. within the channel were also recorded as materials for this study.

Cross-sectional areas $(A)$ of 16 sections were calculated multiplying channel width $(w)$ by average channel depth $(d)$. Maximum channel depths $\left(d_{\max }\right)$ during low water stage were measured directly with the help of dumpy level and meter scale staff. Reduced levels of each cross-section (CS) above mean sea level were calculated from reference height of points determined with the help of Garmin GPS. Surface velocity at low water stage of flow of the river at different stations were measured using bottles as buoyant to measure distance run downstream per unit time by water current. To minimize the effect of wind blowing same direction as river current on floating bottle fastening its velocity and effect of wind blowing opposite direction as river current on floating bottle retarding its velocity, bottles were almost filled with water and only necks were visible above water surface. Hydraulic radius $R$ at a cross-section of a channel is cross-sectional area $A$ divided by wetted perimeter $P$, i.e. $R=A / P$.

Five round measurement of surface velocity at different points of a section were averaged and then multiplied with constant 0.8 to have the average velocity $(v)$ of flow through the channel. Discharges, $Q$ (in $\mathrm{m}^{3} \mathrm{~s}^{-1}$ ) through the channel at 16 stations were calculated multiplying cross-sectional area $(A)$ with mean flow velocity $(v)$. And as the length of the channel under study was too little to find any variation $(0.04 \%)$ in discharge at 16 stations and which was $0.48 \mathrm{~m}^{3} \mathrm{~s}^{-1}$.

Energy needed to perform geomorphologic work by a stream is supplied by the flowing water through the channel and termed as kinetic energy $E_{k}$. Kinetic energy $E_{k}=\frac{1}{2} m v^{2}$ at different cross-sections was calculated. But determination of kinetic energy at a station requires some volume of water which is absurd for at a station cross-section. So for this purpose, formula was rewritten using differential calculus as follows:

$$
\begin{gathered}
E_{k}=\frac{1}{2} \times m \times v^{2} \\
E_{k}=\frac{1}{2} 1000 \mathrm{~A} \times l \times v^{2}
\end{gathered}
$$

If 1 tends to zero, the change in the value of $E_{k}$ for infinitesimally small change of $l$ :

$$
\begin{gathered}
\frac{d E_{k}}{d l}=\frac{1}{2} 1000 \mathrm{~A} \times l \times v^{2} \times \frac{d}{d l} l \\
\frac{d E_{k}}{d l}=\frac{1}{2} 1000 \mathrm{~A} \times v^{2}
\end{gathered}
$$

Since, $A$ and $v^{2}$ are independent of length $(l)$ variable.

Different types of flow behavior were predicted by calculating the ratio between the inertial $\left(v^{2} / d\right)$ and gravitational forces $(g)$. The ratio between these forces is usually expressed as Froude number:

$$
F r=\frac{v}{\sqrt{g d}}
$$

where: $F r$ - Froude number, $v$ - velocity, $g$ - gravitational constant, $d$ - depth. 


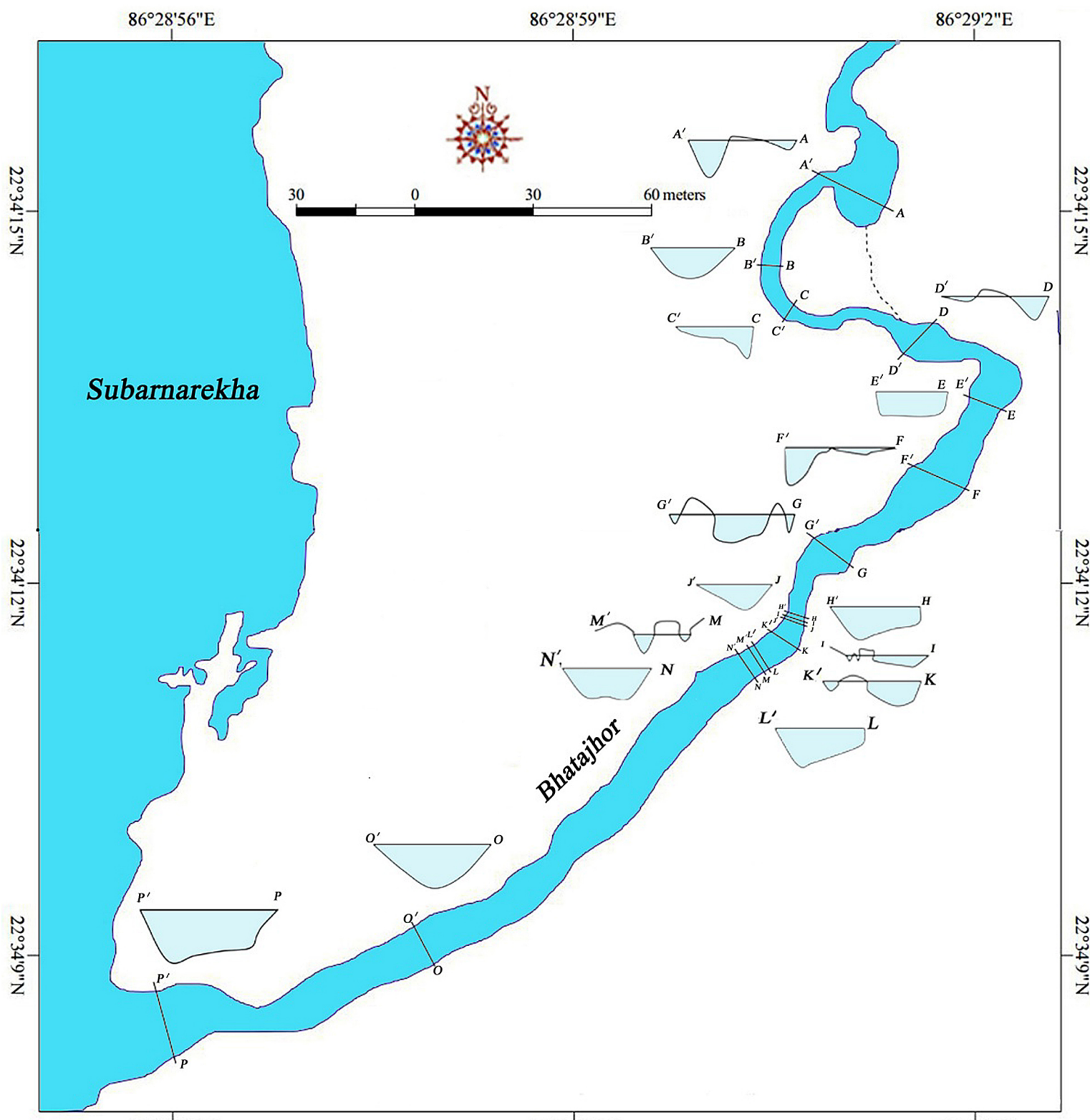

$86^{\circ} 28^{\prime} 56^{\prime \prime} \mathrm{E}$

$86^{\circ} 28^{\prime} 59^{\prime \prime} \mathrm{E}$

$86^{\circ} 29^{\prime} 2 \mathrm{E}$

\begin{tabular}{|c|c|c|c|c|c|c|c|c|}
\hline $\begin{array}{c}\text { Cross } \\
\text { Sections }\end{array}$ & $w / d$ & $\begin{array}{l}\text { Velocity } \\
(\mathrm{m} / \mathrm{sec})\end{array}$ & $\begin{array}{c}\mathrm{KE} \\
\text { (Joule) }\end{array}$ & $\begin{array}{c}\text { Hydraulic } \\
\text { Radius } \\
\text { (m) }\end{array}$ & Froude No & Chézy $\mathrm{C}$ factor & $\begin{array}{c}\text { Shear Stress }(\tau) \\
\left(\mathrm{Kg} \mathrm{ms}^{2}\right)\end{array}$ & $\begin{array}{c}\text { Stream Power( }(\Omega) \\
\left(\mathrm{W} \mathrm{m} \mathrm{m}^{-1}\right)\end{array}$ \\
\hline$A A^{\prime}$ & 46.54162842 & 0.219956857 & 52.70628203 & 0.194016028 & 0.320454192 & 4.7373989 & 23.58383317 & 52.23737799 \\
\hline $\mathrm{BB}^{\prime}$ & 49.32124593 & 0.891198512 & 213.5498787 & 0.093036332 & 0.901977183 & 27.04449936 & 11.95585474 & 54.87345578 \\
\hline $\mathrm{CC}^{\prime}$ & 9.327498848 & 0.220747121 & 52.89564592 & 0.342429022 & 0.480234335 & 1.548871833 & 280.7403807 & 278.8768387 \\
\hline $\mathrm{DD}^{\prime}$ & 23.74662813 & 0.184678998 & 44.2529662 & 0.294417971 & 0.332572141 & 1.913706435 & 102.5786034 & 148.7112925 \\
\hline $\mathrm{EE}^{\prime}$ & 18.1598063 & 0.154718967 & 37.07391357 & 0.363983549 & 0.311424723 & 3.804291893 & 41.84312173 & 48.55443425 \\
\hline $\mathrm{FF}^{\prime}$ & 88.67251096 & 0.300088917 & 71.90760631 & 0.090225989 & 0.344320941 & 15.39448402 & 5.544532703 & 19.79984847 \\
\hline $\mathrm{GG}^{\prime}$ & 21.4605042 & 0.223735761 & 53.61178678 & 0.255303933 & 0.393880786 & 5.954508184 & 17.13879532 & 25.99832638 \\
\hline $\mathrm{HH}^{\prime}$ & 30.66257669 & 1.152994106 & 276.2816006 & 0.095332569 & 1.232228857 & 91.80042969 & 1.88995745 & 7.779421986 \\
\hline$I^{\prime}$ & 9.526875369 & 0.70768163 & 169.5753799 & 0.224983389 & 1.144495377 & 2.503154233 & 929.1854745 & 1670.221428 \\
\hline $\mathrm{J}^{\prime}$ & 16.46090535 & 0.493047325 & 118.1444931 & 0.229787234 & 0.761248145 & 3.252562557 & 238.383 & 470.136402 \\
\hline $\mathrm{KK}^{\prime}$ & 22.10122239 & 0.513877332 & 123.1358002 & 0.141732523 & 0.729480595 & 8.979079894 & 46.56871969 & 108.6449668 \\
\hline $\mathrm{LL}^{\prime}$ & 9.201520913 & 0.145777034 & 34.93123872 & 0.446065129 & 0.353000361 & 0.629197234 & 705.6322419 & 565.7573651 \\
\hline $\mathrm{MM}^{\prime}$ & 3.324362209 & 0.671771797 & 160.9706298 & 0.349705882 & 1.432064117 & 2.702230318 & 803.1141234 & 830.8445035 \\
\hline $\mathrm{NN}^{\prime}$ & 9.582733813 & 0.103537062 & 24.80965439 & 0.575708955 & 0.27034774 & 0.47269931 & 568.1625 & 391.780335 \\
\hline $\mathrm{OO}^{\prime}$ & 11.51585809 & 0.073419764 & 17.59291716 & 0.657343907 & 0.199530312 & 0.746872617 & 108.5755523 & 69.11369725 \\
\hline $\mathrm{PP}^{\prime}$ & 9.09682534 & 0.028353153 & 6.79401082 & 1.06978481 & 0.10368162 & 0.178070954 & 319.9075976 & 112.4728234 \\
\hline
\end{tabular}

Fig. 3. Cross Sections of lower reach of Bhatajhor River (Cross sections are drawn on different scales). 
Stream power $\Omega$ is the rate at which a stream performs its geomorphologic works that is work of erosion and transportation. It is measured in watts per unit channel length, usually $\mathrm{W} \mathrm{m}^{-1}$. Stream power determines the capacity of a given flow to entrain and transport sediment. Stream power is calculated using formula:

$$
\Omega=\rho g Q S
$$

where: $\rho$ - water density, i.e. $1000 \mathrm{~kg} / \mathrm{m}^{3} ; \mathrm{g}$ - acceleration due to gravitational force, i.e. 9.81; $\mathrm{Q}$ - discharge and S - channel slope, i.e. $\mathrm{m} / \mathrm{m}$ ]

Bed shear stresses at different segments of the channel were determined using the formula

$$
\tau_{0}=\rho g h S .
$$

Bed shear stress $\left(\tau_{0}\right)$ is a force per unit area of the bed (in $\mathrm{N} \mathrm{m}^{-2}$ ) and increases with flow depth and steepness of the channel.

\section{Results and Discussions}

\section{Flow Characteristics \& Hydraulics}

Cross-sectional and longitudinal forms of a reach of river channel are shaped by the twoway interactions (Charlton 2008) between processes and hydraulics operating within the channel in one side and lithology and structure along with forms itself on another side. Former group controls shape and size of forms while later group sets the way through which processes and hydraulics will operate to shape the form. Slope along with bed configuration, size, shape and quantity of bed materials determines flow velocity which has a direct control on discharge (Knighton 1998). Velocity in turn modifies slope by cutting and reworking on bed materials and depositing eroded materials. Discharge, flow depth and channel slope determines stream power and shear stress of the river (Gordon et. al. 2004). Stream power is the rate at which a river performs its work of erosion and transportation which in turn controls slope and channel cross-sectional forms. Forms like slope, bed roughness, width, depth, wetted perimeter and hydraulic variables like hydraulic radius, velocity, discharge, power, shear stress interact with each other to adjust themselves in to a system of dynamic equilibrium. If slope is increased, velocity also increases to increase the rate of erosion and deepening of bed. On deeper bed velocity will decrease to follow the Bernoulli principle. Deposition of eroded materials at immediate downstream of deeper pool will cause formation of riffle. On riffle, water depth is less and velocity head is more (Charlton 2008). Increased channel boundary friction slow down the velocity but increase the shear stress and rate of erosion. This in turn smoothen the boundary and increases the hydraulic radius making the channel more efficient (Das 2015). So, processes and form through positive and negative feedback control each other.

This study was carried on lower reach of 345.71 $\mathrm{m}$ of the river Bhatajhor. At 16 cross-sections on this reach average velocity at low water stage was found $0.40 \mathrm{~m} \mathrm{~s}^{-1}$. Highest velocity $1.15 \mathrm{~m} \mathrm{~s}^{-1}$ was recorded at cross-section $\mathrm{HH}^{\prime}$ and lowest velocity $0.03 \mathrm{~m} \mathrm{~s}^{-1}$ at cross-section PP'. At CS $8^{\text {th }}$, average depth is only $0.12 \mathrm{~m}$. So, to follow the principle of Bernoulli and flow continuity (Leopold et al. 1992) velocity head was the maximum. Lowest velocity $0.03 \mathrm{~m} \mathrm{~s}^{-1}$ at CS 16 was because of highest width and depth. Velocity of this channel at lean period is related to $\mathrm{w} / \mathrm{d}$ ratio as follows

$$
\begin{aligned}
& \mathrm{v}=0.111(\mathrm{w} / \mathrm{d})^{0.294} \\
& \text { or } \mathrm{v}=0.111 \mathrm{f}^{0.294}
\end{aligned}
$$

Hydraulic radius is maximum (1.06) at CS $\mathrm{PP}^{\prime}$ which means the most efficient amongst 16 cross-sections. Maximum kinetic energy (276.28 $\mathrm{J} \mathrm{s}^{-2}$ ) is associated with the $\mathrm{CS} \mathrm{HH}^{\prime}$ where velocity is also the highest.

At $\mathrm{CS} \mathrm{HH}^{\prime}$, II' and MM' Froude number greater than 1 indicates the dominance of inertial force and flow type is supercritical. This is because of relatively lower depths but higher channel slope $(0.355 \mathrm{~m} / \mathrm{m}$ at CS II'), highest Chézy's C factor (91.8 at CS HH') and velocity $\left(1.15 \mathrm{~m} \mathrm{~s}^{-1}\right.$ at CS $\left.\mathrm{HH}^{\prime}\right)$. The Chezy's coefficient $(C)$ represents gravitational and frictional forces. Its value decreases with increasing roughness. So, higher the $\mathrm{C}$ factor lower the resistance and higher the velocity (Fig. 4). At rest 13 CS, flow types were found subcritical because Froude number was less than 1 .

Velocity is related to Froude number as

$$
\mathrm{v}=0.146 \mathrm{C}^{0.513} \text {. }
$$




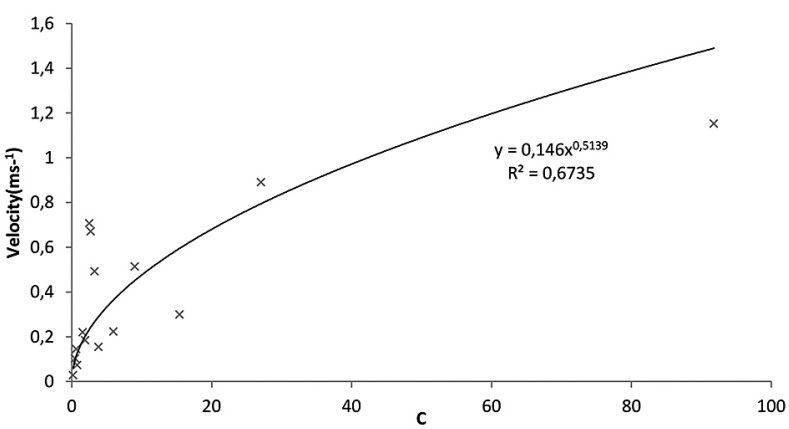

Fig. 4. Relation between velocity and Chezy c factor.

Maximum stream power $1670 \mathrm{Wm}^{-1}$ was recorded at CS II' which is also associated with highest shear stress of 929. As shear stress is dependent directly on discharge which is the product of Av, we found a strong positive correlation $\left(R^{2}=0.885\right)$ between shear stress and velocity. Shear stress depends on velocity as per following equation

$$
\tau=0.274 \mathrm{v}^{1.192} .
$$

Channel slope is another determinant factor of stream power as well as shear stress. During peak season higher discharge is associated with higher stream power which maintains a balance making a change in resistance force of the bed and bank materials. Higher channel slope triggers stream power and higher stream power reduces slope by cutting bed materials and acts as a negative feedback. In case of this study, we found a very strong relation between channel slope and stream power. Where the slope is high stream power was also calculated high. Channel slope also controls shear stress. Higher the channel slope higher is the shear stress. It was found that highest channel slope (0.3553) was at CS II' and lowest (0.002) was at CS HH' which is about $1 / 215^{\text {th }}$ part of the highest slope. Average slope was 0.077 while co-efficient of variation was $142 \%$. This high variability in slope is more regulated by lithology than hydraulics. At CS BB', $\mathrm{DD}^{\prime}, \mathrm{KK}^{\prime}$ and $\mathrm{NN}^{\prime}$ slopes are negative (slope direction towards upstream). This implies that thalweg level of CS EE', LL' and $\mathrm{OO}^{\prime}$ are higher than former CSs and pools have been scoured immediate downstream of $\mathrm{CS}^{\mathrm{B}} \mathrm{B}^{\prime}, \mathrm{DD}^{\prime}, \mathrm{KK}^{\prime}$ and $\mathrm{NN}^{\prime}$. Channel slope and shear stress are related with each other as per following equation

$$
\tau=6587 \mathrm{~s}^{1.192} .
$$

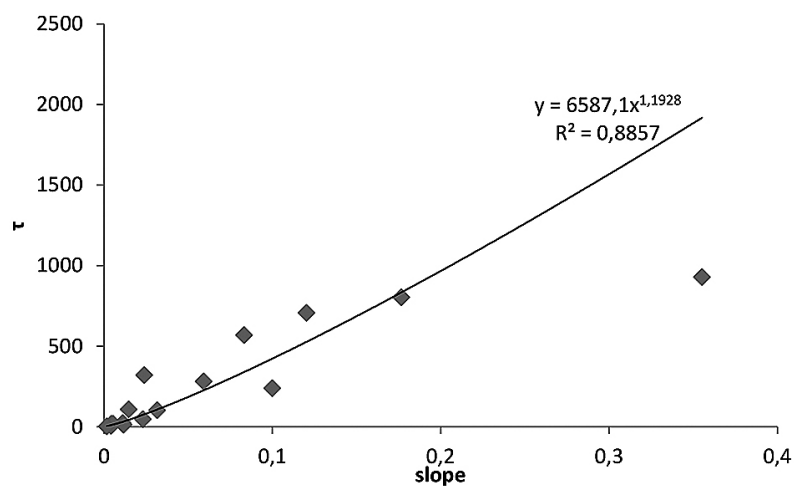

Fig. 5. Relation between Shear stress and slope.

Form these 16 observations it was found that Manning's $n$ factor to a considerable degree $\left(R^{2}=\right.$ 0.671) (Fig. 6) is related to velocity of this kind of small bedrock channel. To find out velocity from Manning's $n$ factor, following formula may be used for small non-perennial bedrock channel of plateau region

$$
\mathrm{v}=0.133 n^{-0.47} .
$$

\section{Forms and hydraulics}

Width of the channel is highly variable having highest value of $12.4 \mathrm{~m}$ and lowest of 1.54 $\mathrm{m}$. This high variability in width is controlled by the confined nature of channel by bedrock substrate. Average width is $6.51 \mathrm{~m}$ with standard deviation of 3.4 and co-efficient of variation of 52.44. As there is no variability in discharge $(0.48$ $\mathrm{m}^{3} \mathrm{~s}^{-1}$ ) within this short length of the channel, principle of flow continuity is maintained by oppositely varied depths. Highest depth $(1.36 \mathrm{~m})$ is more than 13 times greater than the lowest depth of $0.104 \mathrm{~m}$. Co-efficient of variation of depth is

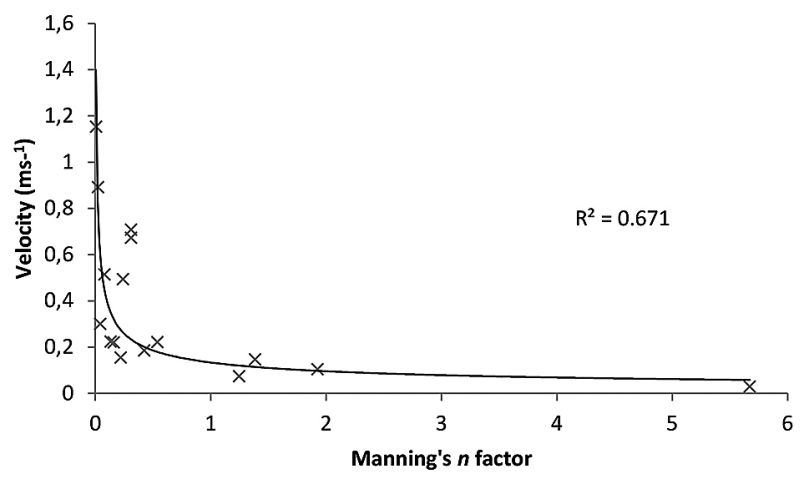

Fig. 6. Velocity decreases with increasing Manning's $\mathrm{n}$ factor. 
$82.4 \%$. This is also controlled by bedrock channel substrate. Hydraulic control on channel parameters width and depth are much less. At CS $\mathrm{AA}^{\prime}$, It was found that hydraulic radius is maximum if $\mathrm{w} / \mathrm{d}$ ranges from 2 to 3 . Beyond this range, hydraulic radius as well as channel's flow efficiency (Das 2015) decreases.

There is a negative correlation between $\mathrm{w} / \mathrm{d}$ and $\mathrm{R}$ (Fig. 7). Co-efficient of determination $\mathrm{R}^{2}=$ 0.531 . This is because of irregular nature of channel bed controlled by rocky substrate. And equation for determining hydraulic radius of such small bedrock channel from given $\mathrm{w} / \mathrm{d}$ ratio is

$$
\mathrm{R}=1.636(\mathrm{w} / \mathrm{d})^{-0.63}
$$

Channel slope controls channel width and depth as well as velocity. Simple understandings suggest that if all other variables are constant then higher slopes are generally associated with low channel width. If slope increases, to maintain energy balance between two reach with constant discharge, velocity head increases. Higher velocity in turn down cut the channel making it relatively deeper in comparison to with. In this channel we found that there was expectedly negative correlation between slope and channel width but quite low (0.32).

There is also definite controls of slope on channel's average depth $\mathrm{d}$ and maximum depth $\mathrm{d}_{\text {max. }}$ As already mentioned higher slope is associated with higher kinetic energy and have much power to perform erosional work by down cutting if base level of erosion is sufficiently below the site of concern. In case of Bhatajhor River, there was an average increase in depth with increased slope. But the correlation between slope

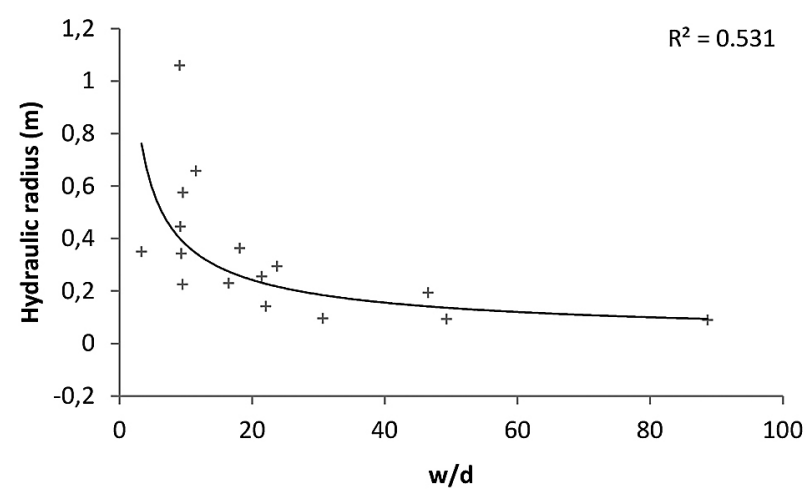

Fig. 7. Higher the Width-depth Ratio lower is the Hydraulic Radius.

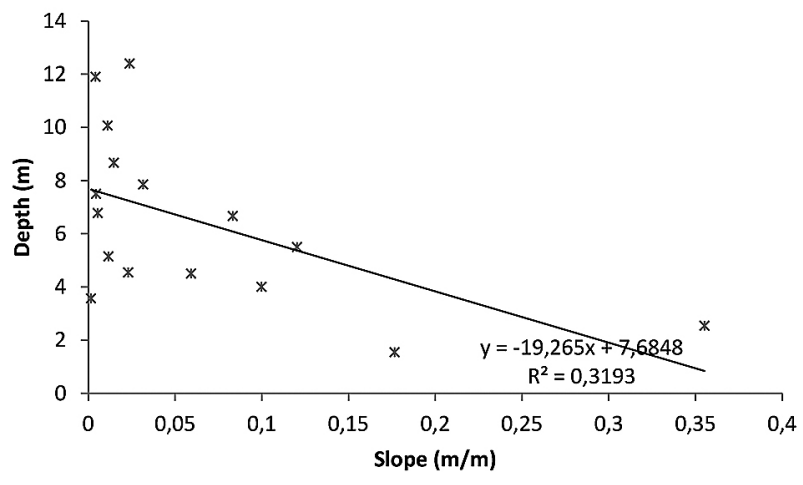

Fig. 8. With higher slope velocity head increases and depth (pressure head) decreases.

and depth is too poor to be mentioned (Fig. 8). This is because of confined nature of the channel within bedrock substrate. Lithological complexity does not allow creating any simple correlation amongst variables.

But as discharge through this short length of the stream is constant, and as velocity (dependent on slope) is one of the important components of discharge, we can try to find out relation between slope and the channel form ratio $(w / d)$. Correlation co-efficient of these two variables was found moderate (0.504) and if slope increased the $\mathrm{w} / \mathrm{d}$ ratio is decreased. For a bedrock channel, w/d ratio may be computed using the equation derived from this study is $\mathrm{w} / \mathrm{d}=4.186$ $\mathrm{s}^{-0.38}$ (Fig. 9).

\section{In channel features}

Different kind of forms such as dolerite outcrops, bars, scarp, dolerite steep wall, riffle, pool etc. formed at lower reach of Bhatajhor River have been studied and it has been found that they are of different dimension and structure. The lower

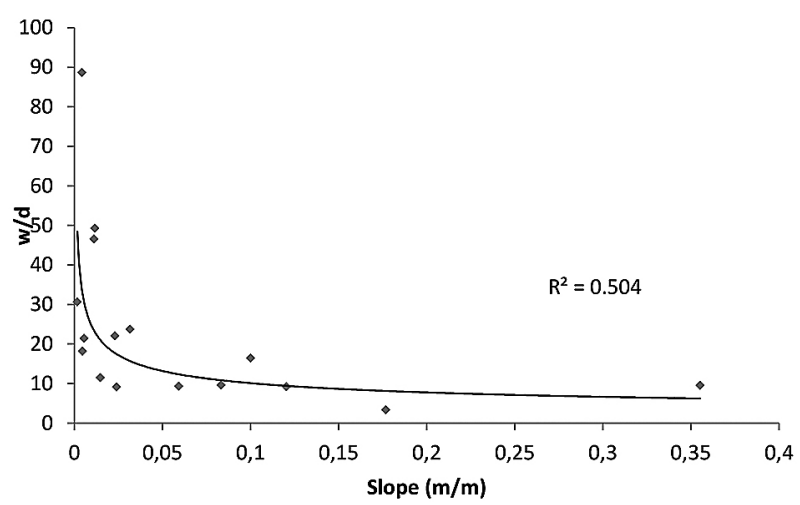

Fig. 9. As slope increases higher velocity restrict widening keeping width depth ratio smaller. 
reach of Bhatajhor River has been divided into three segments viz. upper segment, middle segment and lower segment and each of them has been studied minutely and separately.

\section{Upper Segment}

After accumulation of deposited boulder and gravel, a boulder berm (Fig. 10) is formed at low water stage in the mid channel of upper segment and due to which single flow of the river bifurcates and reunites. The depth of left side flow is deeper than that of right side and a scarp is formed on concave bank. At about $71.72 \mathrm{~m}$ downward from the boulder berm a pool $1.2 \mathrm{~m}$ in depth has been formed along the concave bank of the river due to high flow velocity and stream power and again at about $27.03 \mathrm{~m}$ downward, a mid channel bar (Fig. 10) $6.5 \mathrm{~m}$ in length and $3.35 \mathrm{~m}$ in width has been formed with the association of boulder, gravel and sands. As its bed level is much higher than water level during lean period, pebbles and

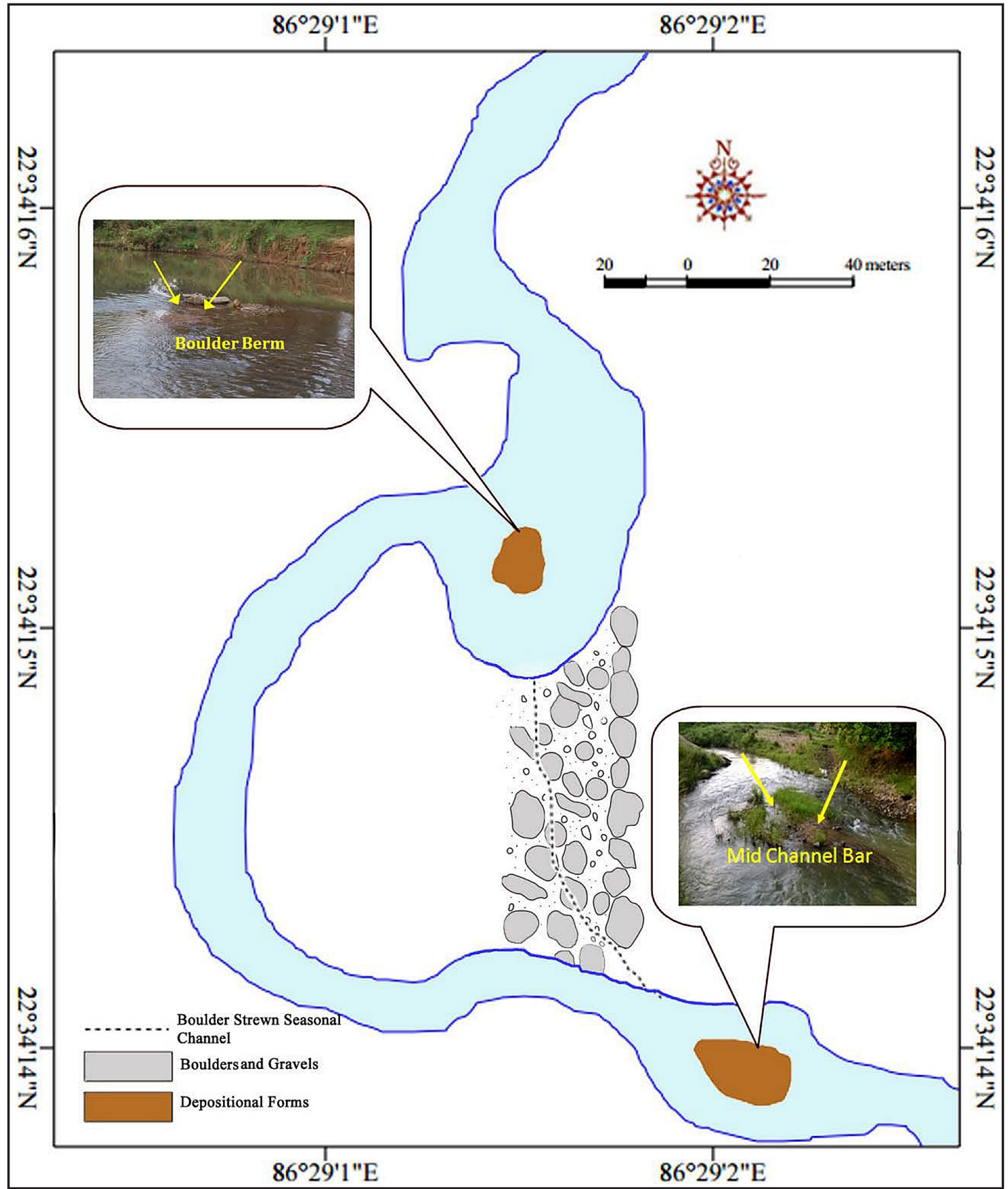

Fig. 10. In-channel forms of Upper Segment. 
boulder strewn left channel of upper segment (Fig. 10) is characterized by seasonality (opened during monsoon months and dry during low water stage) of flow. There is a vegetated fixed island in between the bend of right side channel and the boulder strewn left side channel.

\section{Middle Segment}

In middle segment, due to high flow velocity and stream power, a steep escarpment (Fig. 11) with steep slope has been formed. Immediate downstream of this scarp, the river is flowing through a confined channel in between steep wall of dolerite. Therefore, due to strong resistance to erosion of side walls, the rate of down cutting is higher than that of lateral erosion. So having relatively higher depth and lower velocity (as discharge $Q$ is constant), flow is laminar in nature. At the lower part of middle segment, there is a longitudinal bar (Fig. 11), $4.62 \mathrm{~m}$ in length and $1.1 \mathrm{~m}$ in width. The formation of longitudinal bar is due to low flow velocity facilitating deposition of eroded materials. A few dolerite outcrops formed in the middle segment regulate flow velocity and behaviour.

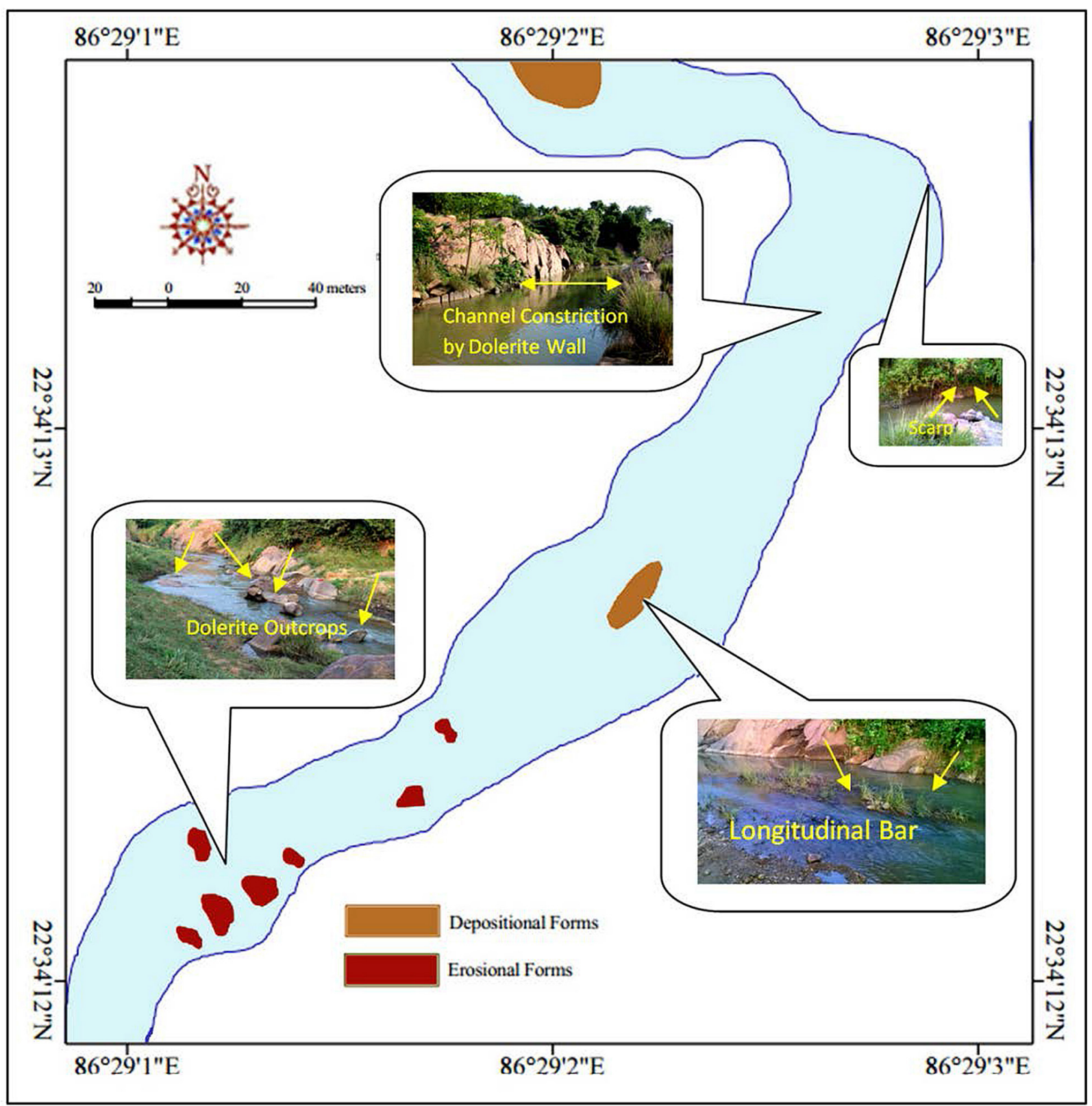

Fig. 11. In-channel forms of Middle Segment. 


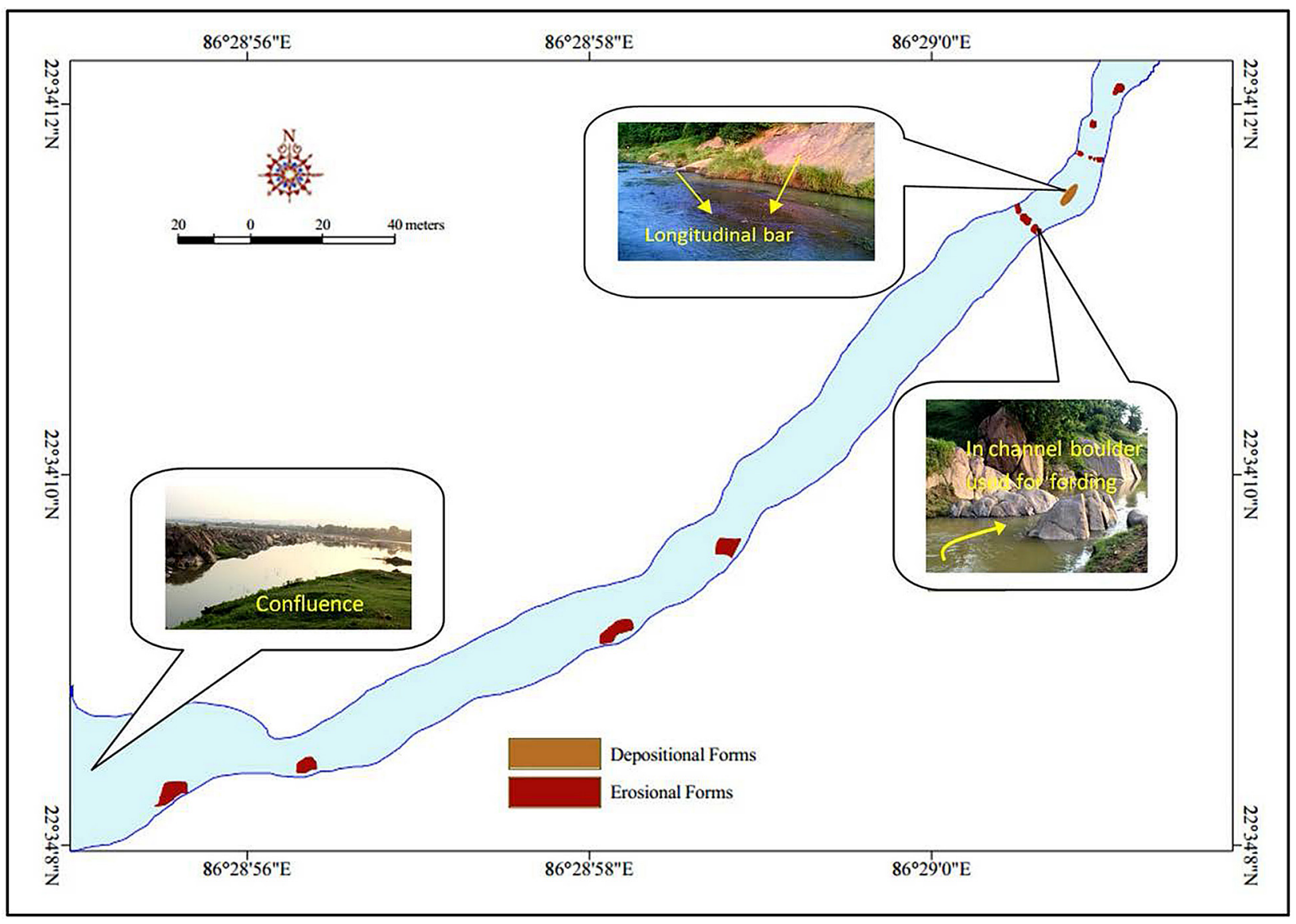

Fig. 12. In-channel forms of Lower Segment.

\section{Lower Segment}

There is little variation among channel forms in lower segment. Many dolerite outcrops (Fig. 12) have been found. A mid channel longitudinal bar (Fig. 12) of $4.7 \mathrm{~m}$ in length and $1.8 \mathrm{~m}$ in width has also been formed by accumulation of gravels, boulders, pebbles and sands. In the middle part of lower segment two large rock obstacles (Fig. 12) are emerged above the low water surface (few larger rock obstacles are emerged even during bank full stage) water stage and are used by the local people as steps for fording. As both the boulders exhibit no root with the base rock, they are reasonably erosional landforms of the lower segment.

\section{Conclusion}

Hydraulics and forms are interrelated components of the fluvial system. Change in any one of these component variables generate stimulus to be responded by other component variables bringing change into themselves and bringing change in the stimulus also. These stimuli-response models are well studied in case of alluvial river system. Bedrock channels may also follow such laws and principles but differently. We tried to find such if any. Velocity of the bedrock channel during it low water stage makes some exponential relationships with Chezy's $C$ factor and Manning's $n$ factor and width/depth ratio. But coefficients and exponents found in this study must differ in different study with difference in space and time. Correlation between shear stress $(\tau)$ and velocity and channel slope are expressed with coefficient 0.27 and 6587 and exponents 1.19 and ${ }^{1.192}$. Hydraulic radius (R) of this wetted channel with low water stage is $1.636 \mathrm{f}^{-0.63}(\mathrm{f}=$ form ratio $=\mathrm{w} / \mathrm{d}$ ). Width $/$ depth ratio in this channel at its low water stage varies with slope with coefficient 4.19 and exponents ${ }^{-0.38}$. But these are obviously not valid for bank full stage or for another river with different physical setup. So to have generalized equations to express hydraulic 
parameters and morphometric variables interactions in bedrock channels much more studies are suggested.

\section{References}

Ashley G.M., Renwick W.H., Haag G.H., 1988. Channel form and process in bedrock and alluvial reaches of the Raritan River, New Jersey. Geology, 16: 436-439. DOI: 10.1130/0091-7613(1988)016<0436: CFAPIB>2.3.CO;2.

Battin T.J., 2008. Biophysical controls on organic carbon fluxes in fluvial networks. Nature Geoscience 1: 95-100

Berner R.A., Berner E.K., 1996. Global Environment: Water, Air, and Geochemical Cycles. Prentice-Hall, Englewood Cliffs, NJ: 376

Charlton R., 2008. Fundamentals of fluvial Geomorphology. Routledge, London-New York: 10-20.

Das B.C., 2015. Modeling of most efficient channel form: a quantitative approach. Modelling Earth Systems and Environment. DOI: 10.1007 /s40808-015-0013-6.

Foley M.G., 1980. Quaternary diversion and incision, Dearborn River, Montana. Geological Society of America Bulletin 91: 2152-2188.

Furguson R.I., 1973. Channel pattern and sediment type. Area 5: 38-41.

Gaillardet J., Dupre B., Allegr C.J., 1999. Geochemistry of large river suspended sediments: Silicate weathering or recycling tracer. Geochimica Cosmochimica Acta 63: 40374051

Galy A., France-Lanord C., 2001. Higher erosion rates in the Himalaya: geochemical constraints on riverine fluxes. Geology 29: 23-26

Galy V., France-Lanord C., Beyssac O., Faure P., Kudrass H., Palhol F., 2007. Efficient organic carbon burial in the Bengal fan sustained by the Himalayan erosional system. Nature 450: 407-410

Gordon N.D., McMahon T.A., Finlayson B.L., 2004. Stream Hydrology An Introduction for Ecologists. Second Edition. John Wiley \& Sons, Chichester.

Gurnell A., Petts G., Hannah D. et al. 2001. Riparian vegetation and island formation along the gravel-bed Fiume Tagliamento, Italy. Earth Surface Processes and Landforms 26: 31-62.

Hancock G.S., Anderson R.S., Whipple K.X., 1998. Beyond power: Bedrock river incision process and form. In: Tinkler K.J., Wohl E.E. (eds), Rivers over rock: Fluvial processes in bedrock channels. American Geophysical Union, Geophysical Monograph 107: 1-323.

Harvey A.M., 1969. Channel capacity and the adjustment of stream morphology to hydrologic regime. J. Hydrol. 8: 82-98.

Huggett R.J., 2002. Fundamentals of Geomorphology. Third edition. Routledge: 21-23

IPCC, Climate Change 2007 Synthesis Report, 2007. An Assessment of the Intergovernmental Panel on Climate Change. Cambridge University Press, Cambridge, UK: 73.

Itakura M., Ikeda H., 1997. On the channel configuration of plane-bed bedrock channels on the upper Obitsu River basin. Bulletin of the Environmental Research Center 22: 9-21.
Kale V.S., Joshi V.U., 2004. Evidence of formation of potholes in bedrock on human timescale: Indrayani River, Pune District, Maharashtra. Current Science 86: 723-726.

Knighton D.A., 1998. Fluvial Forms and Processes: A New Perspective. Arnold, London.

Kobor J.S., Roering J.J., 2004. Systematic variation of bedrock channel gradients in the central Oregon Coast Range: Implications for rock uplift and shallow landsliding. Geomorphology 62: 239-256. DOI: 10.1016/j.geomorph.2004.02.013.

Leopold L.B., Wolman M.G., Miller J.P., 1992. Fluvial Processes in Geomorphology. Dover Publications, INC, New York.

Leopold L.B., Maddock T., Jr., 1953. The hydraulic geometry of stream channels and some physiographic implications. U.S. Geol. Survey Prof. Paper 252: 1-57.

Marzadri A., Tonina D., Bellin A., Vignoli G., Tubino M., 2010. Semi-analytical analysis of hyporheic flow induced by alternate bars. Water Resources Research 46: W07531. DOI: $10.1029 / 2009$ WR008285.

Miller J.R., 1991. The influence of bedrock geology on knickpoint development and channel bed configuration along downcutting streams in south-central Indiana. Journal of Geology 99: 591-605.

Montgomery D.R., Gran K.B., 2001. Downstream variations in the width of bedrock channels. Water Resources Research 7: 1841-1846.

Mosselman E., 2012. Modelling Sediment Transport and Morphodynamics of Gravel-bed Rivers. In: Church M., Biron P.M., Roy A.G. (eds), Gravel-bed Rivers: Processes, Tools, Environments. First Edition. John Wiley \& Sons, Ltd.

Mukhopadhyay S.C., 1980. Geomorphology of the Subarnarekha Basin. the University of Burdwan, Calcutta.

Nikora V., Roy A.G., 2012. Secondary Flows in Rivers: Theoretical Framework, Recent Advances, and Current Challenges. In: Church M., Biron P.M., Roy A.G. (eds), Gravel-bed Rivers: Processes, Tools, Environments. First Edition. John Wiley \& Sons, Ltd.: 18.

Raymo M.E., Ruddiman W.F., 1992. Tectonic forcing of Late Cenozoic climate. Nature 359: 117-122

Raymo M.E., Ruddiman W.F., Froelich P.N., 1988. Influence of late Cenozoic mountain building on ocean geochemical cycles. Geology 16: 649-653.

Reusser L.J., Bierman P.R., Pavich M.J., Zen E., Larsen J., Finkel R., 2004. Rapid Late Pleistocene incision of Atlantic passive-margin river gorges. Science 305: 499-502.

Rhoads B.L., 1992. Statistical models of fluvial systems. Geomorphology 5: 433-455.

Richardson K., Carling P.A., 2005. A Typology of SculptedForms in Open Bedrock Channels. Geological Society of America, Special Paper 392.

Righter K., 1997. High bedrock incision rates in the Atanguillo River valley, Jalisco, western Mexico. Earth Surface Processes and Landforms 22: 337-344. DOI: 10.1002/ (SICI)1096-9837(199704)22:43.3.CO;2-T.

Schumm S.A., 1971. Fluvial Geomorphology: the historical perspective. In: Shen H.W. (ed.), River mechanics. Vol. I. Fort Collins, CO.

Seidl M.A., Weissel J.K., Pratson L.F., 1996. Kinematics of escarpmentbretreat across the rifted continental margin of S.E. Australia: Basin Research 8: 301-316. DOI: 10.1046/j.1365-2117.1996.00266.x.

Selby M.J., 1985. Earth's changing surface. Oxford University Press, Oxford: 262, 607. 
Smith D.I., Greenaway M.A., Moses C., Spate A.P., 1995. Limestone weathering in eastern Australia. P. 1. Erosion rates. Earth Surface Processes and Landforms 20: 451-463.

Stevens M.A., Simons D.B., Richardson E.V., 1975. Nonequilibrium river form. Journal of the Hydraulics Division, ASCE, 101 (HY5): 557-567

Tinkler K.J., Wohl E.E., 1998. Rivers over Rock: Fluvial Processes in bed rock channels. American Geophysical Union, Washington, DC.

Tinkler K.J., Parish J., 1998. Recent adjustments to the long profile of Cooksville Creek, an urbanized bedrock channel in Mississauga, Ontario. In: Tinkler K.J., Wohl E.E. (eds), Rivers over rock: Fluvial processes in bedrock channels. American Geophysical Union, Geophysical Monograph 107: 1-323.

Weissel J.K., Seidl M.A., 1997. Influence of rock strength properties on escarpment retreat across passive continental margins. Geology 25: 631-634. DOI: 10.1130/00917613(1997)025<0631: IORSPO>2.3.CO;2.

Weissel J.K., Seidl M.A., 1998. Inland propagation of erosional escarpments and river profile evolution across the southeast Australian passive continental margin. In: Tinkler K.J., Wohl E.E. (eds), Rivers over rock: Fluvial processes in bedrock channels. American Geophysical Union, Geophysical Monograph 107: 1-323.
Wende R., 1999. Boulder bed forms in jointed-bedrock channels. In: Miller A.J., Gupta A. (eds), Varieties of fluvial form. Wiley and Sons, Chichester.

Whipple K.X., Hancock G.S., Anderson R.S., 2000. River incision into bedrock: Mechanics and relative efficacy of plucking, abrasion and cavitation. Geological Society of America Bulletin 112: 490-503. DOI: 10.1130/00167606(2000)112<490: RIIBMA>2.3.CO; 2.

Whipple K.X., Snyder N.P., Dollenmayer K., 2000b. Rates and processes of bedrock incision by the Upper Ukak River since the 1912 Novarupta ash flow in the Valley of Ten Thousand Smokes, Alaska. Geology 28: 835-838. DOI: 10.1130/0091-7613(2000)028<835: RAPOBI>2.3.CO;2.

Wohl E.E., 2000. Substrate influences on step-pool sequences in the Christopher Creek drainage, Arizona. Journal of Geology 108: 121-129.

Wohl E.E., Achyuthan H., 2002. Substrate influences on incisedchannel morphology. Journal of Geology 110: 115120. DOI: $10.1086 / 324207$.

Wohl E.E., Grodek T., 1994. Channel bed-steps along Nahal-Yael, Negev Desert, Israel. Geomorphology 9: 117-126.

Wohl E.E., Ikeda H., 1998. Patterns of bedrock channel erosion on the Boso Peninsula, Japan. Journal of Geology 106: 331-345.

Wohl E.E., Merritt D.M., 2001. Bedrock channel morphology. Geological Society of America Bulletin 113: 1205-1212. 